\title{
KEJAHATAN TERHADAP ANAK DAN SOLUSINYA MENURUT HUKUM ISLAM
}

\author{
Oleh: \\ Nurwahidah \\ dosen Fakultas Syariah dan Ekonomi Islam IAIN Antasari Banjarmasin \\ (E-mail: nurwahidah97@yahoo.co.id)
}

\begin{abstract}
Children should live a life that is safe and comfortable with their parents and nanny. But the fact is happening, children often face persecution, violence, beatings and harassment, which often lead to death. Islamic law set some rules that may be subject to criminal perpetrators of violence against children committed by parents themselves, not others, while punishment requires an equal position between the perpetrators to the victim. There are scholars argue parents remain exposed qishash, and other scholars argue there is no qishash, just $t a^{\prime}$ 'zir and parents lose their right to inherit property. A lot of cases that occurred in the community in a variety of species, and most perpetrators have been sentenced. However the case that appears only a small part are revealed. In the midst of such conditions should be enforced once hadhanah principles stipulated in Islamic law. Hadhanah emphasize parenting to parents and close family, so that children can be cared for with love and responsibility. So the lives and safety of children will be more secure and protected.

Abstrak: Anak seharusnya menjalani kehidupan yang aman dan nyaman bersama orangtua dan pengasuhnya. Tetapi kenyataan yang terjadi, anak seringkali mengalami penganiayaan, kekerasan, pemukulan dan pelecehan, yang tidak jarang berujung kematian. Hukum Islam mengatur beberapa aturan pidana yang dapat dikenakan kepada pelaku kekerasan terhadap anak. Namun terjadi perbedaan pendapat ulama ketika kekerasan terhadap anak dilakukan oleh orangtuanya sendiri, bukan orang lain, sementara hukuman membutuhkan posisi yang sederajat antara pelaku dengan korban. Ada ulama berpendapat orangtua tetap terkena qisas, dan ulama lain berpendapat tidak ada qisas, hanya ta' 2 ir dan orangtua kehilangan hak mewarisi harta anaknya. Banyak sekali kasus yang terjadi di masyarakat dalam berbagai jenisnya, dan sebagian pelaku sudah dikenakan hukuman. Namun kasus yang muncul tersebut baru sebagian kecil yang terungkap. Di tengah kondisi demikian perlu sekali ditegakkan prinsip-prinsip hadhanah yang diatur dalam Hukum Islam. Hadhanah menekankan pengasuhan anak kepada kedua orangtua dan keluarga dekat, sehingga anak dapat diasuh dengan penuh kasih sayang dan penuh tanggung jawab. Dengan begitu kehidupan dan keselamatan anak akan lebih terjamin dan terlindungi.
\end{abstract}

\section{Keywords: crimes against children, Islamic law, hadhanah.}

\section{Pendahuluan}

Anak adalah aset keluarga yang sangat berharga. Merekalah yang akan menjadi generasi penerus bagi keluarga bersangkutan. Dalam pandangan Islam, tidak hanya di dunia, tetapi anak juga akan menjadi investasi hingga ke akhirat. Sebuah hadits riwayat Muslim menyatakan bahwa anak yang saleh/salehah merupakan warisan amal yang utama bagi orang tua, karena ketika orang tuanya meninggal anak yang saleh tersebut akan mendoakan dan mengirim pahala untuk orang tuanya di alam kubur.

Adapun pemerintah Indonesia sudah berusaha untuk memberikan perlindungan dan perlakuan yang layak terhadap anak dalam bentuk pemberlakukan sejumlah peraturan perundangundangan terhadap anak. Di antara undang-undang tersebut, adalah UU Nomor 4 Tahun 1979 tentang Kesejahteraan Anak, UU Nomor 23 Tahun 2002 tentang Perlindungan Anak, UU Nomor 11 Tahun 2012 tentang Sistem Peradilan Pidana Anak, Undang Nomor 23 Tahun 2004 tentang Penghapusan Kekerasan Dalam Rumah Tangga (UU PKDRT) dan UU Nomor 35 tahun 2014 tentang Perubahan terhadap UU Nomor 23 Tahun 2002 tentang Perlindungan Anak. Sejalan dengan itu pemerintah bersama kalangan aktivis yang peduli juga proaktif 
mendirikan dan menggiatkan lembaga-lembaga yang bergerak di bidang perlindungan anak, seperti Komisi Nasional Perlindungan Anak (Komnas PA) di tingkat pusat, Komisi Perlindungan Anak (KPA) di tingkat daerah, Tim Terpadu Perlindungan Anak (T2PA) dan lembaga serupa lainnya.

Meskipun demikian, kenyataannya perlakukan para orang tua dan masyarakat terhadap anak pada umumnya masih jauh dari harapan. Banyak sekali terjadi kasus kejahatan terhadap anak, mulai dari penelantaran, pemukulan, kekerasan, penganiayaan, pelecehan seksual terhadap anak, perdagangan anak, bahkan ada juga pembunuhan terhadap anak. Banyak pula terjadi orang atau perusahaan mempekerjakan anak-anak di bawah umur dengan upaya yang tidak layak. Tidak jarang juga ditemui adanya anak cacat baik secara fisik maupun psikis (detardasi mental) disembunyikan oleh orang tuanya, tidak diobati dan tidak ditampakkan ke pubik karena malu.

Kejahatan terhadap anak tersebut ada yang terjadi di lingkungan keluarga, sekolah, panti asuhan, tempat penampungan, perusahaan, dan sebagainya. Media massa cetak dan eletronik seringkali memberitakan kasus-kasus tersebut. Di antara kasus-kasus kejahatan dan perlakuan yang tidak manusiawi terhadap anak tersebut ada yang terjangkau oleh aparat penegak hukum kemudian diadli dan diselesaikan, namun tidak mustahil masih lebih banyak lagi yang tersembunyi. Artinya kasuskasus demikian ibarat gunung es, yang muncul ke permukaan hanya bagian puncak kecilnya saja.

Kenyataan demikian, perlu sekali disikapi dan dicarikan solusinya, baik menurut pendekatan hukum yang berlaku di Indonesia, pembinaan dan perlindungan, maupun juga melalui pendekatan Hukum Islam. Hukum Islam memiliki perlakuan yang jelas terhadap anak, oleh karena itu penting pula untuk dikenalkan agar dapat membangun kesadaran khususnya bagi masyarakat yang mayoritas beragama Islam.

\section{Urgesi Perlindungan Anak Beberapa Definisi terkait Anak}

Menurut Undang-Undang 35 tahun 2014 tentang Perubahan terhadap UU Nomor 23 Tahun 2002 tentang Perlindungan Anak, pasal 1, yang dimaksud dengan Anak adalah seseorang yang belum berusia 18 (delapan belas) tahun, termasuk anak yang masih dalam kandungan. Perlindungan Anak adalah segala kegiatan untuk menjamin dan melindungi Anak dan hak-haknya agar dapat hidup, tumbuh, berkembang, dan berpartisipasi secara optimal sesuai dengan harkat dan martabat kemanusiaan, serta mendapat perlindungan dari kekerasan dan diskriminasi.

Pihak pertama yang bertanggung jawab terhadap perlindungan anak adalah keluarga. Keluarga merupakan unit terkecil dalam masyarakat yang terdiri atas suami istri, atau suami istri dan anaknya, atau ayah dan anaknya, atau ibu dan anaknya, atau keluarga sedarah dalam garis lurus ke atas atau ke bawah sampai dengan derajat ketiga.

Orang Tua adalah ayah dan/atau ibu kandung, atau ayah dan/atau ibu tiri, atau ayah dan/atau ibu angkat. Ketika ayah dan/atau ibu berhalangan mengasuh anak, maka pengasuhan tersebut dapat dipindahkan kepada wali. Wali adalah orang atau badan yang dalam kenyataannya menjalankan kekuasaan asuh sebagai Orang Tua terhadap Anak.

Apabila orang tua dan/ wali tidak sanggup mengasuh anak tersebut, maka bisa saja anak tersebut diasuh oleh orang lain, dan statusnya menjadi anak angkat, sedangkan pengasuhnya menjadi orang tua angkat. Anak Angkat adalah Anak yang haknya dialihkan dari lingkungan kekuasaan Keluarga Orang Tua, Wali yang sah, atau orang lain yang bertanggung jawab atas perawatan, pendidikan, dan membesarkan Anak tersebut ke dalam lingkungan Keluarga Orang Tua angkatnya berdasarkan putusan atau penetapan pengadilan.

Dalam kehidupan sosial, ada pula anak yang berstatus sebagai anak asuh. Anak Asuh adalah Anak yang diasuh oleh seseorang atau lembaga untuk diberikan bimbingan, pemeliharaan, perawatan, pendidikan, dan kesehatan karena Orang Tuanya atau salah satu Orang Tuanya tidak mampu menjamin tumbuh kembang Anak secara wajar.

Di tengah masyarakat ada juga anak yang dalam kondisi terlantar dan mengalami kelainan tertentu. Anak Terlantar adalah Anak yang tidak terpenuhi kebutuhannya secara wajar, baik fisik, mental, spiritual, maupun sosial. Kuasa Asuh adalah kekuasaan Orang Tua untuk mengasuh, mendidik, memelihara, membina, melindungi, dan menumbuh-kembangkan Anak sesuai dengan agama yang dianutnya dan sesuai dengan kemampuan, bakat, serta minatnya. Hak Anak adalah bagian dari hak asasi manusia yang wajib dijamin, dilindungi, dan dipenuhi oleh Orang Tua, Keluarga, masyarakat, negara, pemerintah, dan pemerintah daerah. Masyarakat adalah 
perseorangan, keluarga, kelompok, dan organisasi sosial dan/atau organisasi kemasyarakatan.

\section{Dasar Perlindungan}

Anak dengan berbagai macam status sebagaimana disebutkan di atas, berhak untuk mendapatkan perlindungan dari orang tua, wali atau pengasuhnya. Di dalam ajaran Islam kewajiban untuk mengasuh dan melindungi anak ini sudah sangat jelas. Di dalam Alquran surah al-Baqarah/2 ayat 233 diterangkan:

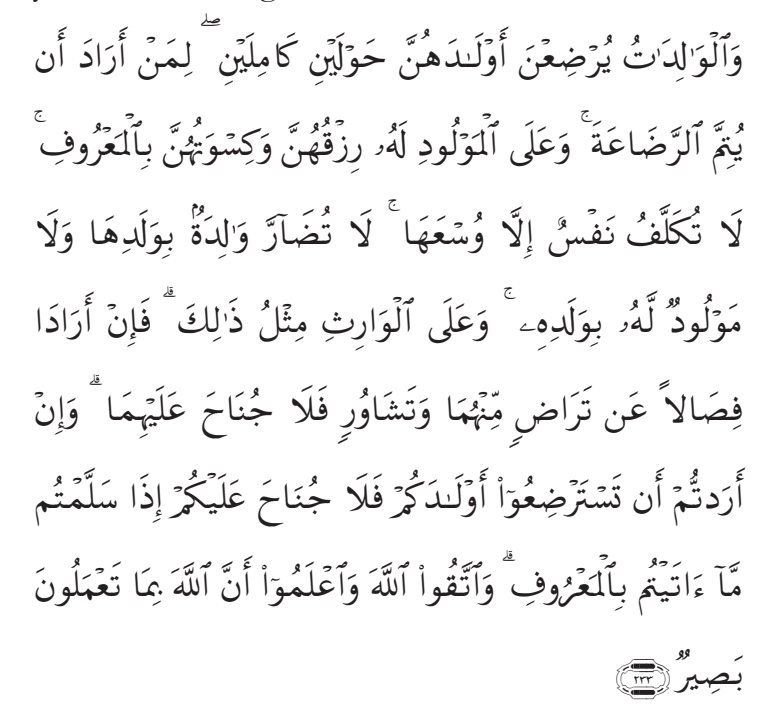

(Para ibu hendaklah menyusukan anak-anaknya selama dua tahun penuh, Yaitu bagi yang ingin menyempurnakan penyusuan. dan kewajiban ayah memberi makan dan pakaian kepada para ibu dengan cara ma'ruf. Seseorang tidak dibebani melainkan menurut kadar kesanggupannya. janganlah seorang ibu menderita kesengsaraan karena anaknya dan seorang ayah karena anaknya, dan warispun berkewajiban demikian. apabila keduanya ingin menyapih (sebelum dua tahun) dengan kerelaan keduanya dan permusyawaratan, maka tidak ada dosa atas keduanya. dan jika kamu ingin anakmu disusukan oleh orang lain, Maka tidak ada dosa bagimu apabila kamu memberikan pembayaran menurut yang patut. bertakwalah kamu kepada Allah dan ketahuilah bahwa Allah Maha melihat apa yang kamu kerjakan).

Menurut Ahmad Musthafa al-Maraghi ${ }^{1}$, ayat di atas menerangkan mengenai kewajiban ayah dan ibu dalam hal pengasuhan dan pemberian nafkah kepada anak. Termasuk di dalamnya perihal penyusuan ketika anak tersebut masih bayi.

Bagi ibu yang masih berfungsi sebagai istri maupun yang sudah dalam kondisi tertalak

1 Ahmad Musthafa al-Maraghi, Tafsir al-Maraghi, Juz 2 (Semarang: Toha Putra, 1993) h. 3418-3419 berkewajiban untuk menyusui anak-anak mereka selama dua tahun dan tidak lebih daripada itu,dan boleh kurang jika ada alasan dan kemaslahatannya. Islam menekankan kepada ibu untuk mengasuh dan menyusui sendiri anaknya karena pengasuhan ibu dan air susu itu merupakan yang terbaik, sebagaimana diakui oleh para dokter. Bayi yang berada dalam kandungan ditumbuhkan dengan darah ibunya, maka setelah ia lahir tetap bertumbuh kembang dengan darah ibunya, dalam hal ini adalah air susu ibu (ASI). ASI adalah makanan utama bagi bayi ketika ia sudah terpisah dari kandungan ibunya. Hanya ASI yang paling cocok dan sesuai dengan perkembangan si bayi. Tidak ada yang perlu dikhawatirkan kalau akan terserang penyakit atau cedera disebabkan oleh ASI, bahkan akan membuatnya lebih sehat dan kuat.

Apabila pengasuhan dan pemberian ASI diserahkan kepada perempuan lain karena ibunya berhalangan atau dalam kondisi darurat, maka perempuan yang mengasuhnya harus diteliti lebih dahulu mengenai kesehatan dan juga akhlak atau kepribadiannya, sebab air susu yang diisapnya akan menjadi darah, daging dan tulang. Saking pentingnya pengasuhan dan pemberian ASI, bahkan Kaisar Rusia memerintahkan agar istri-istri mereka untuk mengasuh dan menyusui anak-anak mereka sendiri, dan melarang dengan keras diasuh dan disusukan oleh orang lain.

Bersamaan dengan kewajiban ibu mengasuh dan menyusui anaknya, maka kewajiban ayah adalah memberi nafkah untuk istri dan anak-anaknya. Diwajibkan bagi seorang ayah untuk menanggung kebutuhan hidup istri dan anaknya berupa makanan, pakaian dan tempat tinggal, agar istrinya itu dapat mengemban tugas pengasuhan terhadap anaknya dengan sebaik-baiknya dan terhindar dari penyakit.

Meskipun demikian, dalam hal menafkahi anak dan istri (keluarga) ini, seorang ayah tidak dibebani melainkan sebatas kemampuannya saja. Artinya ia tidak boleh merasa tertekan dan terbebani secara berlebihan dalam menafkahi anaknya. Semuanya harus disesuaikan dengan kadar kemampuannnya. Hal ini dipertegas oleh QS at-Thalaq/ 65 ayat 7 yang artinya: "Hendaknya orang yang mampu memberi nafkah menurut kemampuannya. Dan orang yang disempitkan rezekinya hendaklah memberi nafkah dari harta yang diberikan Allah kepadanya. Allah tidak memikulkan beban kepada seseorang melainkan sekadar apa yang Allah berikan kepadanya. Allab kelak akan memberikan kelapangan sesudab kesempitan". 
Alquran surah an-Nisa/ 4 ayat 9 menyebutkan:

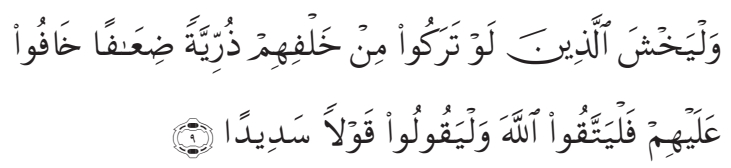

(Dan hendaklah takut kepada Allah orang-orang yang seandainya meninggalkan di belakang mereka anak-anak yang lemah, yang mereka khawatir terhadap (kesejahteraan) mereka. Oleh sebab itu hendaklah mereka bertakwa kepada Allah dan hendaklah mereka mengucapkan perkataan yang benar).

Menurut Ahmad Musthafa al-Maraghi ${ }^{2}$, maksud dari ayat di atas adalah menekankan kepada para orang tua, wali dan orang-orang yang mengasuh anak agar mereka memperlakukan anakanak itu dengan baik, bersikap dan berbicara kepada anak-anak dengan baik, dengan bahasa yang sopan, halus, memanggil mereka dengan anakku, sayangku, dan sebagainya. Kalau anak yang diasuhnya adalah anak orang lain, maka ia harus memperlakukan sama dengan anaknya sendiri.

Allah swt sangat menekankan pengasuhan secara baik dan sopan kepada anak yang tidak lagi memiliki orang tua, baik karena meninggal dunia, bercerai dan sejenisnya. Hal ini karena mereka sangat perasa, tidak boleh tersinggung oleh perkataan yang bernada marah dan menghina, apalagi jika orang tuanya yang sudah tiada disebutsebut dengan nada jelek. Sudah pasti orang tua yang meninggalkan anak tersebut (meninggal dunia atau alasan lain) menginginkan anak tersebut diasuh dengan baik, bahkan melebihi kebaikan pengasuhan saat mereka hidup. Al-Maraghi menyayangkan, karena dalam kenyataannya banyak sekali anak yang berada dalam pengasuhan orang lain, tidak mendapatkan perlakuan yang baik sebagaimana telah diberikan tuntunannya oleh Alquran.

Apabila orang tua anak telah meninggal dunia, dan anak itu diasuh oleh walinya atau orang lain, sementara anak itu memiliki harta warisan, maka pengasuhnya boleh mengambil sebagian dari harta anak itu untuk biaya pengasuhannya, dan menyerahkan harta itu kelak kepada anak ketika anak itu sudah dewasa. Dilarang keras pengasuhnya memakan harta anak itu secara zhalim (QS an-Nisa ayat 10$)$.

Diceritakan bahwa salah seorang sahabat Anshar bernama Aus ibn Shamit meninggal dunia, ${ }^{2}$ Ibid, Juz, 4, h.349. dengan meninggalkan seorang istri dan tiga orang anak wanita yang masih kecil. Kenyataannya, dua anak pamannya yang bernama Suaid dan Arfathah, menguasai harta warisan Aus tersebut, sementara istri Aus dan anak-anaknya tidak mendapatkan apaapa sehingga hidup mereka terlantar. Kemudian istri Aus mengadu kepada Rasulullah mengenai hal tersebut.

Selanjutnya Rasulullah memanggil kedua orang tersebut dan menanyakan alasan mereka menguasai harta warisan peninggalan Aus. Mereka menjawab bahwa anak-anak Aus masih kecil, tidak bisa menunggang kuda, tidak bisa berperang dan tidak mampu membawa beban. Merekalah yang mampu melakukannya, jadi merekalah yang berhak atas harta tersebut.

Jawaban kedua orang tersebut adalah bagian dari tradisi Jahiliyah, bahwa anak kecil tidak beroleh harta warisan. Semboyan di masa Jahiliyah adalah: "Tidak boleh mewarisi kecuali orang-orang yang pandai berperang, menusuk musuh dengan tombak dan panah dan mampu merebut harta ghanimah dalam peperangan, maksudnya sudah dewasa".

Rasulullah kemudian menghapus pandangan ini, dengan memberikan $2 / 3$ harta peninggalan Aus untuk ketiga anak wanitanya, 1/8 untuk istri Aus dan selebihnya untuk kedua anak pamannya. Peristiwa ini menjadi sabab al-nu₹ul turunnya QS an-Nisa ayat $10 .^{3}$

\section{Beberapa Kasus Kejahatan Dan Penelantaran Anak}

Media massa cetak dan elektronik sering sekali memberitakan berbagai kasus terkait dengan anak. Ada dalam bentuk penganiayaan, pembunuhan, penelantaran, pelecehan seksual dan sebagainya. Berikut ini dikemukakan beberapa kasus.

\section{Deskripsi Umum Kasus}

\section{Pemukulan Anak Kandung Hingga Meninggal}

Seorang ayah di Makassar Sulawesi Selatan telah memukul anaknya secara berlebihan. Ayah yang berstatus pengangguran itu pada suatu kali tidur. Ketika mendengar anaknya berisik, maka ia bangun dan mengamuk. Anak tersebut langsung dipukul dengan balok dan tepat mengenai belakang kepala, hingga anak tersebut pingsan. Setelah beberapa hari dirawat di rumah sakit, anak tersebut meninggal dunia. Menurut pengakuan

\footnotetext{
3 Qamaruddin Saleh, Asbabun Nuzul (Bandung : Diponegoro,1999) h. 122
} 
istrinya, suaminya itu menganggur dan tidak dapat memenuhi kebutuhan keluarga, sehingga sang istri dan anak yang baru berusia 12 tahun itu bekerja. Si anak bekerja sebagai penjaga parkir, tidak jauh dari rumah. Namun si ayah malu setelah tahu anaknya mencari uang. Ia menganggap hal itu menodai harga dirinya. Maka ia pun memukul anak tersebut. Kini ayah tersebut buron dan dalam pengejaran aparat kepolisian. Ia dapat dikenai ancaman pidana maksimal 15 tahun (Indosiar dan TV One, 7 Juli 2015).

\section{Penganiayaan, Penelantaran dan Pembunuhan}

Contoh kasus yang paling heboh terkait hal ini adalah kematian Angeline, bocah berusia 9 tahun. Angeline adalah anak Hamidah dan Rosidiq, yang kemudian dijadikan anak angkat oleh keluarga Margriet Christina Megawe, yang tinggal di jalan Sedap Malam Denpasar Bali. Angeline dijadikan anak angkat sejak berusia 3 hari, disebabkan Hamidah dan suaminya tidak sanggup menebus biaya rumah sakit ketika melahirkan anak tersebut. Selama dalam pengasuhan, Hamidah tidak boleh menjenguk anaknya tersebut dan rencananya hanya boleh dijenguk ketika sudah berusia 18 tahun.

Pengasuhan Angeline mengandung kontroversi. Ia tampak disayang oleh ibu angkatnya, khususnya ketika suami Margriet seorang pengusaha minyak asal Amerika masih hidup. Namun belakangan Angeline tidak lagi diasuh sebagaimana mestinya. Menurut guru Angeline, anak tersebut dalam kondisi tertekan, sakit, kurus dan badannya kotor karena tiap hari diwajibkan memberi makan ayam peliharaan Margriet dalam jumlah banyak. Setiap ditanya, Angeline ketakutan dan menutup diri, tidak berani menceritakan nasib yang dialami di rumahnya bersama ibu angkatnya.

Sampai akhirnya Angeline dinyatakan hilang oleh ibu angkatnya (Margriet) dan kakak angkatnya (YVonne). Mereka menebar informasi lewat jejaring sosial untuk meminta tolong kepada masyarakat mencarikan Angeline yang hilang. Ternyata Angeline bukannya hilang, melainkan dibunuh dan kuburnya ditemukan justru di lingkungan rumah Margriet sendiri. Terkait kasus ini yang semula dijadikan sebagai terangka oleh Polda Bali adalah pembantu rumah tangga yang bekerja di rumah keluarga tersebut, yaitu Agustai Mandamai asal Kupang Nusa TenggaraTimur. Belakangan polisi juga menetapkan Margriet sebagai tersangka, karena bukti kuat hasil uji forensik dan lie detector (alat penguji kebohongan) dan keterangan sejumlah saksi, maka Margrietlah tersangka utama pembunuhan Angeline. (TVOne, 25/6-5 Juli 2015).

\section{Penyiksaan Anak oleh Kedua Orangtua}

Media massa di Banjarmasin juga pernah memberitakan perihal penganiayaan dan penyiksaan terhadap anak. Salah satunya adalah yang dialami oleh Muhammad Ilmi, bocah berusia 5 tahun yang bersama orang tuanya tinggai di Desa Asam-asam Kecamatan Jorong Pelaihari Tanah Laut. Ia sering disiksa oleh ibu tirinya yang bernama Nori alias Inor (28 tahun) serta ayah kandungnya sendiri Syahriani.

Anak tersebut sering dipukul, dianiaya dan dikerangkeng oleh ibu tiri dan ayah kandungnya. Ibu kandungnya sendiri sudah meninggal dunia. Penyebabnya karena pelaku kesal terhadap kelakuan Muhammad Ilmi yang dianggap nakal dan menjengkelkan. Atas laporan warga yang tidak tega melihat penderitaan yang dialami oleh Muhammad Ilmi, Kepolisian Resort Pelaihari kemudian menangkap dan menahan kedua tersangka pelaku (ibu tiri dan ayah korban). Kedua pelaku diancam dengan pasal berlapis tentang penganiayaan dan penelantaran, sebagaimana diatur dalam UU nomor 23 tahun 2002 tentang Perlindungan Anak, UU KDRT dan juga pasal 351 KUHP.

Berdasarkan hasil penyelidikan oleh Badan Pemberdayaan Perempuan dan Keluarga Berencana Kabupaten Tanah Laut, tindak kekerasan yang dilakukan oleh kedua orang tua terhadap korban sudah berlangsung selama dua tahun. Akibatnya fisik Muhammad Ilmi mengalami luka dan lebam, pertumbuhan badannya tidak optimal, sering sakit, belum lagi psikisnya terganggu karena dihantui rasa takut dan tidak penggembira sebagaimana anakanak kebanyakan seusianya. Anak tersebut juga tidak disekolahkan di TK karena kedua orang tua tidak mau memperhatikannya.

Saat diasuh oleh kedua orangtuanya, M. Ilmi hanya ditempatkan di sebuah kamar kecil menyerupai kandang, terbuat dari bambu yang terletak berdampingan dengan WC. Tempat tidurnya hanya tikar dan bantal. Ketua PKK Tanah Laut Arry Suryandini yang merupakan istri Bupati Bambang Alamsyah mengaku sedih dan prihatin melihat perlakuan kedua orang tua M. Ilmi tersebut, sehingga karena luasnya wilayah ada nasib anak yang tidak terpantau (Kalimantan Post, 11 Juli 2015).

\section{Penganiayaan Sehingga Anak lari dari Rumah}

Perlakuan jenis ini dapat diwakili oleh kasus penganiayaan seorang anak bernama GT oleh ibu 
kandungnya sendiri bernama Leasa Sharon Rosa. Kejadiannya di sebuah wilayah di Jakarta Selatan. Pada tubuh anak tersebut terdapat luka-luka lebam, dan bekas sayatan. Anak tersebut kemudian lari dan diselamatkan oleh para tetangga, selanjutnya ditangani oleh pihak Kementerian Sosial. Namun dalam kasus ini sang ibu membantah. Ia mengatakan sebagai ibu kandung sayang pada anaknya, tidak mungkin melakukan penganiayaan. (TVOne, 8 Juli 2015).

\section{Pemukulan Anak Sekolah}

Guru di sekolah juga sering memukul anakanak didiknya, karena mereka melakukan perbuatan yang tidak baik atau dianggap melanggar suatu tata tertib sekolah. Sebuah pondok pesantren di Jawa melakukan pemukulan dengan cara dicambuk. Anak-anak yang bersalah diikat pada satu tiang dengan wajah tertutup. Setelah itu guru-guru yang bertugas secara bergantian memukul anak tersebut. Pemukulan harus disaksikan oleh para santri lainnya agar mereka bisa mengambil pelajaran dan tidak melakukan kesalahan serupa (TVOne, 15-16 Maret 2015).

Di sekolah-sekolah atau pesantren lain hukuman terhadap siswa/santri masih sering terjadi. Ada yang ditempeleng, dijewer telinganya, ditendang, dijemur di panas matahari, disuruh berkeliling lapangan, membersihkan WC dan kamar mandi dan sebagainya. Di antara siswa/santri tersebut ada yang sampai sakit, ada orang tuanya yang keberatan hingga melaporkan guru/sekolah ke kepolisian dan sebagainya.

\section{Pelecehan Seksual}

Kasus pelecehan seksual terhadap anak sering terjadi, baik yang dilakukan oleh keluarga dekat maupun orang lain. Yang dilakukan oleh keluarga dekat dapat dicontohkan pada kasus $\mathrm{U}$, yang memperkosa dua anak perempuan tiri yang tinggal bersamanya. $U$ yang berstatus duda mengawini $J$ yang juga janda. Saat membina rumah tangga bersama U, J membawa serta tiga orang anak gadisnya, masing-masing berusia 9,11 dan 13 tahun ke rumah U.

Ketiga anak tersebut ikut ibunya dan ayah tirinya, karena ayah kandungnya dan keluarga ibunya enggan memelihara, dengan alasan ekonomi. $\mathrm{U}$ pun sebenarnya tidak begitu mampu secara ekonomi, karena ia hanya berjualan di pasar-pasar dan tinggal di rumah sewa yang kecil. Walaupun J sudah diperingatkan oleh teman-temannya akan risiko membawa anak perempuan, namun ia tidak punya pilihan. J merasa yakin dirinya sendiri masih sanggup melayani kebutuhan biologis U. Jadi tidak mungkin $\mathrm{U}$ menjamah anak tirinya yang masih di bawah umur.

Setelah tinggal bersama di rumah $U$ inilah terjadi pemerkosaan kedua anak wanita tersebut oleh U. Mulanya yang diperkosa adalah yang paling tua, hal ini dimaafkan oleh J, lalu anak tersebut diungsikan ke keluarga lain, tanpa dilaporkan ke pihak yang berwajib. Ternyata hal itu tidak membuat U jera, tidak lama kemudian giliran adiknya yang diperkosa. Pemerkosaan dilakukan lebih dari satu kali, bahkan U sempat berkilah bahwa perkosaan hanya dilakukan di masa-masa awal, selanjutnya mereka sudah saling mau. Ayah dan anak tiri itu melakukannya saat ibu (J) tidak ada di rumah.

Untunglah kedua anak wanita itu tidak hamil. Setelah mendapati kenyataan ini maka dengan sangat terpaksa J mengadukan U ke polisi, selanjutnya $\mathrm{U}$ ditahan dan sempat dipenjara selama 3 tahun. Antara U dengan J pun sempat berpisah, namun setelah $\mathrm{U}$ keluar dari penjara mereka rujuk. Sekarang semua anak tersebut tidak ada lagi yang tinggal bersama mereka, mereka tinggal bersama keluarga lain yang bersedia menampung.

Kasus pelecehan seksual terhadap anak juga terjadi pada sebuah sekolah internasional di Jakarta. Ini merupakan sekolah elit di mana pengasuh dan para pengajarnya umumnya orang asing, dan muridmuridnya adalah anak orang-orang kaya. Sejumlah anak di sekolah tersebut ternyata pernah mengalami pelecehan seksual, yaitu disodomi, yang diduga dilakukan oleh guru dan pegawai sekolah. Setelah kasusnya terbongkar sejumlah tersangka dikenakan hukuman dan sekolah tersebut direkomendasikan untuk ditutup.

\section{Penculikan dan Perdagangan Anak}

Selain kasus-kasus di atas, ternyata penculikan anak untuk diperdagangkan juga biasa terjadi. Diceritakan di salah satu tempat di Jawa Barat terjadi penculikan bayi dan bocah. Bayi yang ada di rumah sakit, melalui teknik sedemikian rupa untuk mengelabui para petugas rumah sakit (bidan, perawat, dokter) dan lain-lain, berhasil diculik. Ada juga bocah-bocah yang sedang bermain, kemudian diiming-imingi dengan hadiah tertentu, kemudian diajak meninggalkan rumahnya, kemudian diculik (TVOne, 8 Juli 2015).

Kasus penculikan bayi dan bocah ini bukan untuk minta tebusan, melainkan untuk diperjualbelikan. Hal ini dicurigai dilakukan oleh 
sindikat perdagangan bayi/anak, baik untuk dijual keluar negeri atau keperluan lain. Dikhawatirkan ke depannya anak-anak tersebut nantinya akan dijadikan pelayan seksual di negara atau tempat tertentu.

\section{Pendekatan Hukum}

Terhadap kasus-kasus pidana (jarimah/jinayah) sebagaimana disebutkan di atas, meskipun terjadi dalam lingkungan keluarga, bila ditinjau dari Hukum Pidana Islam, ada yang terkena hukuman qisas, hadd dan ta'zir.

\section{Pemukulan, penganiayaan hingga meninggal}

Hukum Pidana Islam mengatur perihal qisas untuk pembunuhan dan penganiayaan. Untuk pembunuhan, dapat dibagi tiga, yaitu pembunuhan sengaja (al-qatlu al-amdu), pembunuhan semi sengaja (al-qatlu syibbul amdi) dan pembunuhan karena kekhilafan atau tidak sengaja (al-khatlu al-khata). ${ }^{4}$

Kita amati kasus yang terjadi di Sulawesi Selatan, seorang ayah memukul anaknya dengan balok kayu mengenai belakang kepala lalu anak itu tewas, maka dapat dipastikan hal itu dilakukan secara sengaja. Meskipun ayah tersebut sedang emosi, ia tentu tahu bahwa balok kayu merupakan benda berbahaya jika dipukulkan ke bagian fisik yang vital.

Terkait hal ini Sayyid Sabiq $q^{5}$ mengatakan, jarimah pembunuhan yang menuntut diberlakukannya qisas disyaratkan bahwa pembunuh bukan orang tua dari si terbunuh. Artinya orang tua tidak diqisas dengan sebab membunuh anak kandungnya, cucunya dan seterusnya sekalipun disengaja. Hal ini berdasar kepada sebuah hadits yang diriwayatkan oleh Ibn Umar bahwasanya Nabi SAW., bersabda: la yuqtalu al-walidu bi al-waladi (ayah tidak diqisas karena membunuh anaknya). Hadits ini diriwayatkan oleh Imam al-Turmudzi dan menurut Ibn Abdil Barr hadits ini diamalkan oleh penduduk Madinah dan diketahui secara luas oleh para ahli ilmu di Hijaz dan Irak. Berbeda jika si anak yang membunuh orangtuanya, maka wajib qisas atas anak tersebut.

Diriwayatkan oleh Yahya bin Said, dari Amr bin Syuaib, bahwa ada seorang laki-laki dari Bani Mudlij bernama Qatadah. Ia melemparkan pedang kepada salah seorang anaknya, dan ternyata mengenai kaki, lalu terjadi pendarahan yang hebat, kemudian anak tersebut tewas. Suraqah bin Jusy'um

\footnotetext{
4 Ahmad Hanafi, Asas-Asas Hukum Pidana Islam (Jakarta, Bulan Bintang, 1990) h.8.

5 Sayyid Sabiq, Fikih Sunnah, Juz 10, alih bahasa M. Thalib (Bandung: Al. Ma.arif, 1987), h. 49.
}

kemudian melaporkan kejadian itu kepada Umar, lalu Umar berkata kepadanya: Sediakanlah di Maa Qadid 120 ekor unta. Ketika Umar datang, beliau mengambil 30 ekor unta hiqqah dan 30 ekor unta jadz'ah dan 40 ekor khilfah. Lalu Suraqah yang merupakan saudara dari orang yang meninggal itu diberikan oleh Umar unta-unta tersebut. Sedangkan untuk ayahnya yang membunuh tidak mendapatkan apa-apa, karena orang yang membunuh dari orang yang akan mewariskan tidak memperoleh apa-apa. Jadi intinya pembunuh kehilangan hak waris dari orang (yang akan mewariskan) yang dibunuhnya. Tetapi Imam Malik berpendapat lain, orang tua (ayah atau ibu) tetap terkena hukuman qisas jika pembunuhan yang dilakukannya bersifat sengaja, artinya ia secara lahiriyah menggunakan senjata atau alat atau benda-benda yang memang dapat melukai dan membahayakan jiwa seseorang. Bukan sekadar mau mendidik karena kasih sayangnya pada anak ${ }^{6}$

Sedangkan terhadap kasus Margriet di Denpasar Bali, maka dapat dikenakan hukuman qisas karena dikategorikan sebagai pembunuhan sengaja. Unsur kesengajaan ini terlihat dari fakta penelantaran Angeline sekian lama, dan sudah ada lubang kubur yang disiapkan. Tetapi ada pakar hukum yang menyatakan bahwa pembunuhan atas Angeline tidak disengaja, Angeline hanya dibenturkan ke tembok, lalu terkapar dan tewas. Tetapi unsur kesengajaan di sini juga terlihat sangat kuat, sebab tembok (semen/beton) adalah benda keras, dan fisik Angeline yang masih anakanak sudah lemah, jadi risiko bahaya kematian seharusnya sudah diketahui oleh pelaku. Jangankan anak-anak, orang dewasa pun jika dibenturkan ke tembok bisa menyebabkan kematian.

Apakah pelakunya Margriet sendiri, atau bersama Agustai atau lainnya, maka pelakunya dapat dikenakan hukuman qisash tersebut, tergantung perannya. Bagi pelaku utama ia terancam qisas pembunuhan sengaja, sedangkan bagi pelaku lain dapat dimasukkan dalam pelaku penyerta.

Berkaitan dengan hal ini Hukum Pidana Islam yang dirumuskan oleh para fuqaha membagi perbuatan turut berbuat pidana dalam dua kategori. Pertama, orang yang turut berbuat secara langsung dalam melakukan tindak pidana (syarik mubasyir), dan perbuatannya disebut isytiraq mubasyir. Kedua, orang yang tidak turut berbuat secara langsung dalam melakukan tindak pidana (syarik mutasyabbib),

${ }^{6}$ Ibid, h. 50. 
dan perbuatannya disebut isytirak bil-tasabbubi atau isytirak ghairu mubasyir.

Terhadap kedua jenis perbuatan tersebut, ulama Hanafi hanya mengenakan hukuman kepada syarik mubasyir, sedangkan syarik, ghairu mubaysir tidak disinggung-singgung. Namun bagi fuqaha lain di luar Mazhab Hanafi, untuk kasus pembunuhan dan penganiayaan, baik pelaku langsung maupun tidak langsung keduanya terkena hukuman. Alasannya, dalam tindak pindana pembunuhan dan penganiayaan dapat dilakukan secara langsung dan tidak langsung. Kalau perbuatan tidak langsung terlepas dari ancaman hukuman, maka akan banyak terjadi tindak pidana tidak langsung tersebut, dan hal ini sangat berbahaya, sebab orang akan makin berani menggunakan orang lain dalam melakukan kejahatannya. Karena itu orang yang menyuruh, menghasut, membayar (upah), juga termasuk ke dalam pelaku jarimah. Namun kepada mereka ini hukumannya tidak sama dengan pelaku utama, melainkan hanya hukuman $t a^{\prime} \not i r{ }^{7}$

Untuk kasus Margriet, kalau benar dia pelaku utamanya, maka dalam pandangan Hukum Pidana Islam, ia dapat dikenakan hukuman qisas pembunuhan. Tidak ada keraguan di sini, sebab Margriet merupakan ibu angkat dari Angeline, bukan ibu kandungnya. Agustai, yang dikabarkan ikut menguburkan anak tersebut, juga dapat dikenakan sebagai pelaku penyerta sesuai dengan tingkat perannya dalam pembunuhan tersebut.

\section{Pemukulan dan Penganiayaan}

Hukum Islam membolehkan orangtua memukul anaknya, tetapi tujuannya untuk mendidik, bukan untuk menganiaya dan menyakiti yang membahayakan fisik dan psikis anak. Dalam pelaksanaan pendidikan baik di sekolah maupun di luar sekolah (keluarga dan masyarakat), apabila disampaikan dengan cara yang lemah lembut, menyentuh perasaan sering memperoleh keberhasilan, tetapi apabila dalam cara mendidik disampaikan dengan keras atau terlalu lembut maka akan membuat jiwa tidak stabil. Karena jiwa tidak bedanya dengan anggota tubuh yang apabila dimanjakan dengan sifat lemah jika akan diberikan pekerjaan yang kasar dan keras tentu tidak akan tahan untuk melaksanakannya, begitu juga dengan jiwa. Oleh karena itu "dalam mendidik anak perlu juga sedikit disampaikan dengan menggunakan cara yang sifatnya keras yaitu berupa pemberian sanksi

Ahmad Hanafi, op.cit., h. 138. atau hukuman"8 Pendidikan yang disampaikan dengan cara lemah lembut tanpa didasarkan atas paksaan atau kekerasan akan lebih baik dari pada pendidikan yang disampaikan dengan cara yang keras karena hal ini akan berpengaruh besar kepada kejiwaan anak. Pendidikan yang disampaikan dengan cara yang keras membuat anak takut dan tegang dalam proses belajar mengajar, sehingga tujuan yang ingin dicapai dalam proses belajar mengajar tidak bisa tercapai dengan baik.

Dalam pendidikan di sekolah, sikap keras kadang juga diperlukan pada anak agar supaya bisa berdisiplin, karena sikap yang lemah lembut atau nasehat saja kadang tidak mampu membuat anak menjadi baik atau jera untuk melakukan kesalahan maupun pelanggaran. Oleh karena itu penerapan sanksi atau hukuman adalah salah satu jalan dalam upaya pembentukan dan perbaikan disiplin siswa di sekolah. Hukuman dan sanksi yang diterapkan bertujuan agar anak yang melanggar peraturan sekolah bisa berdisiplin dan tidak lagi mengulangi perbuatannya. Tanpa adanya sanksi atau hukuman membuat siswa tidak ada rasa takut untuk melanggar peraturan dan akan terus mengulangi lagi perbuatannya.

Dalam pembelajaran di sekolah harus ada unsur yang saling berkaitan dan menunjang antara yang satu dengan yang lainnya sehingga tujuan akhir dari pendidikan dapat berjalan dengan baik. Salah satu unsur yang terkait dan cukup menunjang adalah kebijakan sekolah yang berkenaan dengan tata tertib sekolah khususnya penerapan sanksi atau hukuman dalam meningkatkan disiplin belajar siswa di sekolah.

Hukuman dalam pendidikan Islam adalah salah satu cara dalam membentuk dan memperbaiki disiplin, akan tetapi hal ini bukanlah jalan yang utama. Dalam penerapan disiplin terlebih dahulu ada tahapan-tahapan yang harus dilalui, sebelum hukuman itu dilaksanakan. Tahapan-tahapan yang harus dilalui itu adalah apabila teladan dan nasehat tidak mampu lagi maka waktu itu harus dilakukan tindakan tegas yang dapat meletakkan persoalan di tempat yang benar. Tindakan tegas itu adalah sanksi atau hukuman yang harus memiliki nilai edukatif. Sanksi atau hukuman tidak perlu diterapkan bagi anak yang masih mau mendengarkan nasihat dan teladan gurunya, karena pendidikan dengan

\footnotetext{
8 Sulaiman Harun, Sistem Pendidikan Islam, (Jakarta: Cipta Karya, 2001), h. 343.
} 
menggunakan sanksi kadang membawa dampak psikologis yang buruk bagi anak.

Hukuman dalam keluarga dibolehkan sepanjang untuk mendidik, sebagaimana disebutkan dalam sebuah hadits yang berbunyi:

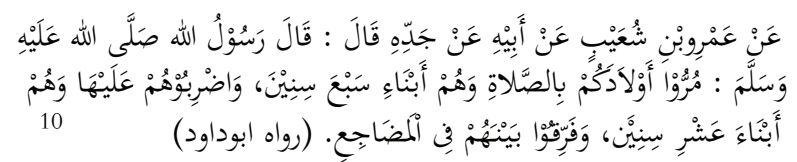

Artinya: Dari Amru bin Syuaib dari ayahnya dari kakeknya berkata: Bersabda Rasulullah saw: Suruhlah anak-anakmu shalat ketika mereka berusia tujuh tahun, dan pukullah (jika tidak mau shalat) ketika mereka berusia 10 tahun, dan pisahkan tidur antara anak laki-laki dengan perempuan.

Penerapan sanksi untuk meningkatkan disiplin siswa di sekolah walaupun masih dalam keadaan pro dan kontra akan tetapi pada kenyataannya masih banyak lembaga pendidikan sekarang yang masih menerapkannya, khususnya di Pondok Pesantren, tetapi di sekolah-sekolah umum sudah jarang ditemukan.

Penerapan sanksi secara psikologis akan lebih efektif dari pada sanksi fisik karena sanksi secara psikologis tidak menyakiti anak dan akan membuat anak menjadi sadar sendiri bahwa perbuatan yang dilakukannya itu adalah salah. Pengaruh sanksi fisik lebih banyak bersifat negatif dari positifnya, misalnya anak akan menjadi benci dengan guru yang menjatuhkan sanksi, sakit hati, dendam dan sebagainya. Sanksi fisik juga lebih bersifat memaksa atau lebih bersifat otoriter bukan didasarkan atas kesadaran sendiri, sehingga memungkinkan anak untuk mengulangi lagi pelanggaran di lain waktu.

Penerapan sanksi dalam proses pendidikan terdapat pro dan kontra. Mengacu kepada hadits di atas, Muhammad Athiyah al-Abrasyi membolehkan orangtua menghukum anaknya dengan syarat: (a) Sebelum anak berusia 10 tahun tidak boleh dihukum; (b) Kalau terpaksa menghukum anak maka alat pemukulnya tidak boleh yang membahayakan fisik anak, cukup hanya lidi kecil; (c) Tidak boleh memukul anak pada bagian fisik anak yang berbahaya seperti perut, dada, muka, kepala, kemaluan, dan lain-lain; (d) Sebelum memukul anak harus didahulukan jalan lain berupa nasihat

\footnotetext{
${ }^{10}$ Al-Imam Abu Daud Sulaiman ibn al-Asy'Ats al-Sijistani, Sunan Abi Daud, Jilid 2, (Surabaya, Maktabah Dahlan Indonesia,tth) h. 133.
}

dan bimbingan ${ }^{11}$

Emile Durkheim kurang setuju dengan diterapkannya sanksi dalam meningkatkan disiplin siswa, ini tergambar dari pendapatnya tentang disiplin dan hukum sekolah. "Hukum tidak memberikan wewenang kepada disiplin, tetapi mencegah disiplin kehilangan wewenangnya. Perlakuan keras dibenarkan hanya sejauh hal itu diperlukan dan membuat celaan terhadap tindakan yang dilakukan menjadi benar-benar jelas"12 dan bahwa tindakan yang diberikan kepada siswa untuk menghentikan pelanggaran adalah memberikan sanksi atau hukuman ${ }^{13}$

Adapun sanksi terbagi dua, yaitu preventif dan represif. Sanksi preventif diberikan dengan maksud agar tidak atau jangan sampai terjadi pelanggaran, maksudnya untuk mencegah jangan sampai terjadi pelanggaran. Sanksi represif, diberikan oleh karena adanya pelanggaran, kesalahan atau dosa yang telah diperbuat oleh anak. ${ }^{14}$

Hukuman dengan cara pemukulan, pelukaan dan penganiayaan anak, baik oleh orang tuanya maupun gurunya, jika sampai berakibat fatal pada anak, maka hal tersebut dapat dikenakan sanksi hukum. Menurut Hukum Islam ia terkena qisas, sesuai dengan penganiayaan dan kesakitan atau kecacatan yang dirasakan oleh anak. Berlakunya qisas ini mengacu kepada QS al-Baqarah ayat 194: "Dan barangsiapa yang menyerang kamu, maka seranglah seimbang dengan serangannya kepadamu", juga dalam QS al-Syüra ayat 40: "Dan balaslah suatu kejahatan dengan kejahatan yang serupa". Jadi jika seseorang mendapatkan tempelengan, tendangan, pukulan dan pelukaan atau cacian dari seseorang, maka hal serupa atau setimpal juga dapat dilakukan terhadap pelaku. Hakikat qisas adalah merealisasikan keadilan, dan demi keadilan itulah sehingga hukuman qisas diberlakukan. ${ }^{15}$ Namun karena berlakunya hukuman qisas di sini menuntut adanya kesederajatan antara

\footnotetext{
${ }^{11}$ Muhammad Athiyah al-Abrasyi, al-Tarbiyah al-Islamiyah wa Falsafatubu, Alih bahasa Bustami Abdulghani dan Djohar Bahry dengan judul Dasar-dasar Pokok Pendidikan Islam, (Jakarta:Bulan Bintang, 1980), h. 155.

${ }^{12}$ Emilie Durkheim, L Education Morale, diterjemahkan oleh Lukas Ginting dengan judui Pendidikan Moral (Jakarta: Erlangga, 2000) h. 14.

${ }^{13}$ Sudirman dkk, Ilmu Pendidikan, Jakarta: Rineka Cipta, 1991) h. 123 .

${ }^{14}$ M. Ngalim Purwanto, Ilmu Pendidikan Teoritis dan Praktis (Bandung: Remaja Posdakarya, 2001) h. 189.

${ }^{15}$ Sayyid Sabiq, op.cit., h. 76-77.
} 
pelaku dengan korban, maka untuk pelaku yang tidak sederajat, misalnya antara orang-tua dengan anak, guru dengan murid, maka hukuman qisas menjadi mustahil diterapkan. Oleh karenanya jenis hukumannya dapat diturunkan menjadi diyat atau ta'zir, di mana hakim dapat menjatuhkan hukuman tertentu untuk pelaku, karena perbuatan yang dilakukannya sangat membahayakan fisik dan jiwa anak/murid.

\section{Pemerkosaan dan Pelecehan Seksual}

Bagi pelaku pemerkosaan maka kepadanya dapat dikenakan hadd zina, namun hukumannya hanya kepada pelaku, sedangkan korban tidak dikenakan. Berbeda dengan perzinaan yang dilakukan atas dasar suka sama suka sehingga yang terkena hukuman adalah keduanya, pria dan wanitanya. Untuk pelaku yang bernama U yang sudah pernah kawin dalam pernikahan yang sah, maka ia tergolong pezina mubshan dan hukumannya dirajam sampai mati atau hukuman lain yang diatur dalam Fikih.

Untuk pelecehan seksual dalam bentuk sodomi, maka pelaku juga dapat dikenakan hukuman, sedangkan anak-anak sebagai korban tidak terkena hukuman. Para ulama Fikih berbeda pendapat mengenai hukuman terhadap pelaku sodomi, yaitu:

a. Bahwa pelakunya harus dibunuh secara mutlak;

b. Bahwa pelakunya harus dikenakan hadd sebagaimana hadd zina, jika masih perjaka maka didera dan jika mubshan maka dirajam sampai mati;

c. Pelakunya harus diberi sanksi di luar hadd zina, sebab homoseks berbeda dengan zina antara pria dengan wanita ${ }^{16}$

\section{Penculikan dan Perdagangan Anak}

Penculikan dan perdagangan anak, yang diduga dilakukan oleh suatu sindikat yang terorganisasi, menurut Hukum Pidana Islam dapat dikategorikan dengan hirabah, meskipun dilakukan secara sembunyi-sembunyi, tidak terang-terangan, ini sama dengan perampokan, pembegalan dan sejenisnya.

Menurut istilah hukum Islam, birabah adalah keluarnya gerombolan bersenjata di daerah Islam untuk melakukan kekacauan, penumpahan darah, perampasan harta, merusak tanaman, peternakan, penodaan agama, kehormatan, akhlak,

\footnotetext{
${ }^{16}$ Sayyid Sabiq, Fikih Sunnah, Juz 9, alih bahasa M. Thalib (Bandung: Al-Ma’arif, 1987), h. 134-136.
}

ketertiban dan pelanggaran terhadap undangundang yang berlaku. Termasuk kategori birabah adalah gerombolan pembunuh, sindikat penculik anak-anak dan penjual perempuan, penggarong rumah, toko dan bank, penculikan pejabat untuk dibunuh, penyebar fitnah agar terjadi kekacauan dan sebagainya. ${ }^{17}$

Hirabah tergolong kejahatan dan dosa besar, dan terhadap pelaku hirabah begini dikenakan hukuman berat, sebagaimana disebutkan QS alMaidah ayat 33. Pelaku dikenakan hadd hirabah, yaitu dibunuh, disalib, dipotong tangan dan kakinya atau dibuang dari negeri tempat tinggalnya. Namun untuk bisa dikenakan hukuman, harus dipenuhi empat syarat, yaitu pelaku birabah orang yang sudah mukallaf (dewasa, normal), membawa senjata, praktik hirabah dilakukan jauh dari keramaian dan secara terang-terangan.

Majelis Ulama Indonesia melalui Ketua Bidang Fatwa MUI Pusat Prof Hasanuddin mengatakan, begal dan penculikan termasuk birabah dalam hukum Islam, pelakunya dapat dikenakan hadd hirabah. Namun untuk Indonesia yang tidak memberlakukan Hukum Islam, Hasanuddin menyarankan diberlakukan hukum potong tangan saja, supaya pelaku jera dan masyarakat menjadi aman dan nyaman. MUI menyerahkan penanganan pelaku kepada penegak hukum dan minta masyarakat tidak melakukan aksi eigen reghting atau main hakim sendiri, karena ada pelaku yang dibunuh dan dibakar hidup-hidup sehingga tewas di tempat (Banjarmasin Post, 3 Maret 2015).

Kasus-kasus lainya juga bertentangan dengan hukum, sebab mengandung unsur kekerasan. Kekerasan adalah setiap perbuatan terhadap Anak yang berakibat timbulnya kesengsaraan atau penderitaan secara fisik, psikis, seksual, dan/ atau penelantaran, termasuk ancaman untuk melakukan perbuatan, pemaksaan, atau perampasan kemerdekaan secara melawan hukum

\section{Penguatan Hadhanah}

Terjadinya berbagai kejahatan yang dilakukan oleh orang tua terhadap anak, atau oleh guru kepada murid, di antara penyebabnya karena kurangnya penghayatan terhadap hakikat hadhanah dan pendidikan pada anak.

Secara bahasa hadhanah atau bidhanah berarti pengasuhan, pemeliharaan bayi atau anak. Menurut pengertian syara' hadhanab ialah pemeliharaan anak 17 Ibid, h. 175. 
yang belum mampu berdiri sendiri mengurus dirinya, pendidikannya serta pemeliharaannya dari segala sesuatu yang dapat membahayakan atau membinasakannya ${ }^{18}$

Menurut Syekh Zainuddin bin Abdul Aziz al-Malibary, hadhanah adalah mendidik anak yang belum bisa mengatur dirinya sendiri. Anak yang mumayyiz lebih utama diasuh oleh ibu yang tidak bersuamikan orang lain. Anak mumayyiz yang ayah ibunya bercerai, hadhanah berada di tangan ayah atau ibu yang dipilihnya. ${ }^{19}$ Ibrahim Muhammad al-Jamal mengatakan, hadhanah ialah hak untuk memelihara anak kecil, baik laki-laki maupun perempuan, atau yang kurang sehat akalnya, tidak termasuk di dalamnya pemeliharaan anak yang telah dewasa. Hadhanah ini merupakan hak yang patut diterima oleh anak kecil, karena dia memang masih memerlukan orang yang sanggup memelihara, membimbing dan mendidiknya dengan baik ${ }^{20}$

Dari keterangan di atas dapat dipahami bahwa hadhanah adalah pengasuhan anak, yang termasuk di dalamnya mengasuh, menafkahi, memelihara, mendidik dan membimbingnya. Kewajiban hadhanah ini berlaku bagi suami istri atau ayah dan ibu dari si anak. Bagi seorang ayah, hadhanah yang sangat diutamakan adalah disegi pemberian nafkah. Sedangkan bagi seorang ibu, hadhanah adalah pengasuhan atau pemeliharaan anak disegi penyusuan, penyapihan, pemberian kasih sayang dan sebagainya.

Ibrahim Muhammad al-Jamal mengatakan, dalam hal hadhanah ini ibulah satu-satunya manusia yang paling sanggup dalam memelihara dan membentuk kepribadian anak itu hingga ia dewasa. Oleh karena itu ibulah yang secara hukum punya kewajiban memelihara putra-putrinya, baik laki-laki maupun perempuan, karena ayah tidak akan sanggup melakukan hal ini ${ }^{21}$

Apabila ibu sebagai orang yang paling berhak melakukan hadhanah berhalangan, maka ada urutan orang-orang tertentu yang berhak mengasuh anak. Lengkapnya urutan hadhanah ini sebagai berikut:

Ibunya sendiri, kalau dia berhalangan, hadhanah jatuh kepada: Ibunya ibu (nenek) dan

${ }^{18}$ Muhammad Ismail al-Kahlani al-Shan'ani, Subul al-Salam, Jilid II, (Beirut:Dar al-Fikr, 1412 H), h. 50

${ }_{19}$ Syekh Zainuddin bin Abdul Aziz al-Malibary, Fathul Mu'in, Jilid 3, alih bahasa Aliy As'ad, (kudus, Menara, 1983), h. 246

${ }^{20}$ Ibrahim Muhammad al-Jamal, Fiqh Wanita, alih bahasa Anshari Umar, (Semarang, asy-Syifa, 1989), h. 450

${ }^{21}$ Ibid seterusnya ke atas. Kalau dia berhalangan maka beralih kepada: Ibunya ayah (nenek), kalau dia berhalangan jatuh kepada: Saudara perempuan yang sekandung dengan anak itu. Kemudian berturut-turut: Saudara perempuan seibu; Saudara perempuan seayah; Anak perempuan dari saudara perempuan sekandung; Anak perempuan dari saudara perempuan seayah; Saudara perempuan ibu yang seibu dengannya; Saudara perempuan ibu yang seayah dengannya; Anak perempuan dari saudara perempuan seayah; Anak perempuan dari saudara laki-laki sekandung; Anak perempuan dari saudara laki-laki seibu; Anak perempuan dari saudara laki-laki seayah; Saudara perempuan ayah yang sekadung dengannya; Bibinya ibu dari pihak ibunya; Bibinya ayah dari pihak ibunya; Bibinya ibu dari pihak ayahnya; Bibinya ayah dari pihak ayahnya. Urutan nomor 16-19 ini dengan mengutamakan yang sekandung pada masing-masingnya.

Kalau anak itu tidak mempunyai kerabat perempuan dari kalangan mahram tersebut, atau ada tetapi tidak dapat mengasuhnya, maka pemeliharaan anak itu beralih kepada kerabat laki-laki yang masih ada muhrimnya atau ashabah sesuai dengan urutan masing-masing dalam persoalan waris. Yang pertama anak itu beralih kepada:

Ayahnya sendiri, selanjutnya kepada: Ayahnya ayah (kakek) dan seterusnya ke atas, kemudian: Saudara laki-laki sekandung; Saudara laki-laki seayah; Anak laki-laki dari saudara laki-laki sekandung; Anak laki-laki dari saudara laki-laki seayah; Paman yang sekandung dengan ayah; Paman yang seayah dengan ayah; Paman ayah yang sekandung dengan ayahnya; Pamannya ayah yang seayah dengan ayahnya. Kalau ashabah dari muhrim laki-laki tidak ada, atau ada tetapi tidak bisa mengasuhnya, maka hadhanah beralih kepada muhrim-muhrim laki-laki selain ashabah yaitu: Ayahnya ibu (kakek)) atau berturut-turut: Saudara laki-laki seibu; Paman yang seibu dengan ayah; Paman yang seibu dengan ibu; Paman yang sekandung dengan ibu, paman yang seayah dengan ibu ${ }^{22}$ Urutan-urutan di atas tidak dijalankan dalam hal pengasuhan anak pada kasus-kasus di atas. Ayah tidak secara langsung berhak mengasuh anak apabila ibunya tidak ada atau berhalangan. Pengasuh anak yang ditekankan adalah di pihak keluarga ibunya. Adapun kedudukan ayah yang utama bukan pada pengasuhan, melainkan sebagai pemberi nafkah, sebab pada umumnya ayahlah yang bekerja dan berpenghasilan yang dari

${ }^{22}$ Ibid, h. 457. 
situ ia dapat menafkahi anak dan istrinya. Menurut al Kahlani, nafkah itu jamak dari kata nafaqah, dan maksudnya adalah segala sesuatu yang diberikan dan dikorbankan oleh manusia yang dia butuhkan sendiri dan yang dibutuhkan orang lain, berupa makanan, minuman dan selain keduanya ${ }^{23}$

Di dalam Kompilasi Hukum Islam (KHI) pasal 80 ayat (4) diperinci nafkah yang menjadi kewajiban suami terhadap anak istrinya, yaitu meliput: Nafkah, kiswah (pakaian) dan tempat kediaman bagi istri; Biaya rumah tangga, biaya perawatan dan biaya pengobatan bagi istri dan anak; dan biaya pendidikan bagi anak. Jadi nafkah itu dalam arti luas tidak hanya makanan, pakaian dan tempat tinggal, tetapi juga biaya pengobatan, pendidikan dan bahkan pembantu rumah tangga yang diperlukan dalam suatu keluarga, dengan melihat kepada kemampuan suami.

Kewajiban ini juga diatur dalam pasal 41 butir b dan c Undang-Undang Nomor 1 tahun 1974 tentang Perkawinan; Putusnya perkawinan karena perceraian bapak yang bertanggung jawab atas semua biaya pemeliharaan dan pendidikan yang diperlukan anak. Bilamana bapak dalam kenyataan tidak dapat memenuhi kewajiban tersebut, pengadilan dapat menentukan bahwa ibu ikut memikul biaya tersebut.

Di dalam Kompilasi Hukum Islam pasal 156 dinyatakan "semua biaya hadhanah dan nafkah anak menjadi tanggungan ayah menurut kemampuannya, sekurang-kurangnya sampai anak itu dewasa dan dapat mengurus diri sendiri (21 tahun). Untuk bisa mengemban tugas hadhanah disyaratkan: Baligh dan berakal; Mampu mendidik anak; Terpercaya dan berbudi luhur; Islam, orang kafir tidak boleh melaksanakan tugas hadhanah anak muslim; Tidak bersuami (belum menikah lagi). ${ }^{24}$

Umar dan Ali pernah memutuskan perkara dengan keputusan bahwa setelah perceraian ibu lebih berhak mengasuh anak, demikian pula dengan Qadhi Syuraih. Pendapat ini adalah pendapat mazhab Syafi'i dan Hanbali. Tetapi Abu Hanifah berpendapat, ayah lebih berhak mengasuh anaknya. Memberi kesempatan memilih kepada anak tidak sah, karena anak tidak dapat menyatakan kehendaknya dan menyatakan tujuannya. Mungkin ia hanya mencari kesenangan, teman bermain, dengan mengabaikan pendidikannya. Hal ini akan merusak diri anak itu ketika telah dewasa. Imam

\footnotetext{
${ }^{23}$ Muhamamad Ismail al-Kahlani al-Shan'ani, op.cit., h. 218.

${ }^{24}$ Ibrahim Muhammad al-Jamal, op.cit., h. 457.
}

Malik menyatakan, ibunya berhak mengasuh anak itu hanya sampai ompong (tanggal gigi mukanya). Hal ini berlaku bagi anak laki-laki. Sedangkan bagi anak perempuan menurut Syafii disuruh memilih. Menurut Abu Hanifah ibu lebih berhak mengasuh sampai anak itu kawin. Sedangkan menurut mazhab Hanbali ayah lebih berhak mengasuhnya tanpa disuruh memilih.dan ibu hanya berhak mengasuh sampai anak itu berusia 9 tahun.

Menurut Ibn al-Qayyim al-Jauzi, yang berhak mengasuh bukan ayah ibunya, tetapi melihat kepada perhatian dan tanggung jawabnya pada anak. Apabila ibu lebih cermat dalam mengasuh anak, lebih sayang dibanding ayahnya, maka ibu lebih berhak tanpa disuruh memilih, karena anak itu masih lemah akal dan otaknya. Apabila anak mengajukan pilihan maka pilihannya itu tidak usah diperhatikan. Ia harus diasuh oleh orang yang lebih bermanfaat dan bertanggung jawab secara syariat. Apabila ibu lebih memperhatikan pendidikan anak, sedangkan ayah mengabaikannya, maka ibulah yang lebih berhak mengasuh anak. Sebaliknya jika pendidikan agama anak lebih terjamin, sedangkan ditangan ibunya terabaikan, maka ayahlah yang berhak mengasuhnya ${ }^{25}$. Sebab Allah Swt. memerintahkan kepada ayah bertanggung jawab atas keluarganya (QS al-Tahrim ayat 6).

Intinya setelah pereraian bapak dan ibu tetap bertanggung jawab pada anak, bapak dan ibu tetap berkewajiban memelihara dan mendidik anak-anak mereka semata-mata untuk kepentingan anak. Apabila ada perselisihan tentang penguasaan anak,maka pengadilan memberikan keputusannya. Bapak bertanggung jawab atas semua biaya pemeliharaan dan pendidikan yang diperlukan anak itu. Apabila bapak dalam kenyataan tidak dapat memenuhi kewajiban tersebut, ibu ikut memikul biaya tersebut. ${ }^{26}$ Jika terpaksa terjadi adopsi, harus dilakukan adopsi secara benar, yaitu mengambil anak orang lain untuk diasuh dan dididik dengan penuh perhatian dan kasih sayang, dan diperlakukan oleh orangtua angkatnya seperti anak kandung sendiri, tanpa memberi status anak kandung kepadanya $^{27}$

\footnotetext{
${ }^{25}$ Muhammmad Ali al-Maliky, Etika Dalam Rumah Tangga Islam, alih bahasaHalimuddin, (Surabaya, Bungkul Indah, tth.), h. 153.

${ }^{26}$ Abdulkadir Muhammad, Hukum Perdata Indonesia (Bandung: Citra Aditya Bakti, 1993), h. 116.

${ }^{27}$ Mahmud Syaltout, al-Fatawa, (Masir, Dar al-Qalam, tth.), h. 321-322.
} 
Melihat kasus-kasus yang terjadi, tampak perlakuan terhadap anak tidak sejalan dengan aturan hadhanah dalam Hukum Islam. Pada kasus penganiayaan dan penelantaran anak di Pelaihari, seharusnya ibu kandungnya yang memelihara atau neneknya atau keluarga ibunya. Sebab ternyata ibu tirinya justru menganiaya dan menelantarkan, begitu juga ayah kandungnya ikut-ikutan menyiksa anaknya.

Pengangkatan anak (adopsi) Angeline juga tidak sesuai dengan Hukum Islam, sebab Angeline berasal dari keluarga muslim dari Banyuwangi, yaitu Hamidah (ibu) dan Rosidik (ayah), sedangkan keluarga Margriet yang mengasuhnya adalah keluarga Nasrani. Hal ini juga tidak sejalan dengan UU Nomor 23 Tahun 2002 tentang Perlindungan Anak, pasal 39 tentang pengangkatan anak yang menyatakan:

1. Pengangkatan anak hanya dapat dilakukan untuk kepentingan yang terbaik bagi anak dan dilakukan berdasarkan adat kebiasaan setempat dam ketentuan perundangundangan yang berlaku;

2. Pengangkatan anak sebagaimana dimaksud dalam ayat (1) tidak memutuskan hubungan darah antara anak yang diangkat dengan orangtua kandungnya;

3. Calon orang tua angkat harus seagama dengan agama yang dianut oleh anak angkat;

4. Pengangkatan anak oleh warganegara asing hanya dapat dilakukan sebagai upaya terakhir;

5. Dalam hal asal usul anak tidak diketahui, maka agama anak disesuaikan dengan agama mayoritas penduduk setempat ${ }^{28}$

Penegasan orang tua anak harus seagama dengan agama anak sangat penting, karena bagi anak muslim akan menjamin masa depan agamanya yaitu kemuslimannya. Orangtua anak angkat pasti menguasai anak angkat bersangkutan, sedangkan Islam tidak mengehendaki orang Islam dikuasai oleh nonmuslim. "Dan Allah tidak akan sekali-kali memberikan jalan kepada orang-orang kafir menguasai orang-orang mukmin" (QS an-Nisa ayat 141).

Berkenaan dengan masalah ini MUI mengeluarkan fatwa sebagai berikut:

1. Islam mengakui kuturunan (nasab) yang

\footnotetext{
${ }^{28}$ Departemen Komunikasi dan Informatika, Penghapusan Eksploitasi Seksual Komersial Anak (Jakarta: Badan Informasi Publik, 2005), h. 88.
}

sah ialah anak yang lahir dari perkawinan (pernikahan) yang sah pula;

2. Mengangkat anak (adopsi) dengan pengertian anak tersebut putus hubungan keturunan nasab dengan ayah dan ibu kandungnya (tabanni) bertentangan dengan syariat Islam.

3. Pengangkatan anak dengan tidak mengubah status nasab dan agamanya, dilakukan atas rasa tanggung jawab sosial untuk memelihara, mengasuh dan mendidik mereka dengan penuh kasih sayang seperti anak sendiri, adalah perbuatan terpuji dan termasuk amal saleh yang dianjurkan Islam ${ }^{29}$

Orangtua, keluarganya dan juga pemerintah harus berupaya mencegah agar tidak terjadi anak muslim diangkat anak oleh nonmuslim, sebab dikhawatirkan agamanya akan ikut berubah menjadi seagama dengan orangtua angkatnya, sebab faktor asuhan dan didikan sangat dominan dalam mengubah dan mewarnai religiusitas seseorang. Kasus Angeline, yang disyaratkan tidak boleh ditemui ibunya hingga usia 18 tahun, sangat mungkin Angeline sekiranya tidak terbunuh, juga akan beragama seperti agama ibu angkatnya.

Tetapi sebagai penduduk yang pluralitas di bidang agama, bisa saja terjadi keluarga anak dari keluarga nonmuslim bersedia diangkat anak oleh keluarga muslim, atau sebaliknya disertai kesediaan untuk pindah agama (konversi) menjadi muslim. Ada kasus pasangan muslim yang sudah dikaruniai tiga orang anak mengajukan permohonan pengangkatan anak yang berasal dari keluarga nonmuslim, karena kedua orangtua anak yang akan diangkat itu tidak keberatan anaknya menjadi muslim ${ }^{30}$. Hal begini tidak menjadi masalah, tetapi kalau anak muslim diangkat anak oleh keluarga nonmuslim seperti kasus Angeline, maka di segi agama saja sudah menjadi masalah.

\section{Penutup}

Adanya sejumlah anak yang menjadi korban kejahatan berupa kekerasan, baik oleh orangtuanya maupun orang lain, menuntut perlunya pengasuhan dan perlindungan secara bertanggung jawab. Selain penegakan hukum, prinsip hadhanah sebagaimana tuntunan Islam perlu dilaksanakan, keluarga menjadi

\footnotetext{
${ }^{29}$ Majelis Ulama Indonesia(MUI), Himpunan Fatwa MUI, (Jakarta: Departeman Agama RI, 2003), h. 178.

${ }^{30}$ Karsayuda,Pengangkatan Anak dari Keluarga Nonmuslim di Pengadilan Agama, Bahan Perkuliahan, 2006, h.1
} 
pihak yang paling utama untuk bertanggung jawab.

Pemerintah perlu lebih banyak lagi menyediakan lembaga yang bergerak di bidang perlindungan anak, dan hal ini sudah dilakukan, tinggal gerakannya yang harus lebih aktif dan antisipatif, dan diperlukan pula pekerja sosial yang mempunyai komitmen tinggi untuk melindungi anak disertai kompetensi profesional dalam bidangnya.

Bagi anak-anak yang rawan penganiayaan oleh orang tuanya, diperlukan perlindungan khusus, yaitu suatu bentuk perlindungan yang diterima oleh Anak dalam situasi dan kondisi tertentu untuk mendapatkan jaminan rasa aman terhadap ancaman yang membahayakan diri dan jiwa dalam tumbuh kembangnya. Orang tua atau pihak mana saja yang terbukti melakukan penganiyaan dan pembunuhan terhadap anak, perlu dikenakan hukuman berat sesuai hukum yang berlaku.

Lembaga pendidikan hendaknya menjadi tempat yang aman dan nyaman bagi anak didik. Kecenderungan pendidik menghukum anak atas nama pendidikan hendaknya dihindari, sebab mendidik bukan menghukum dan menyakiti. Pendidikan harus lebih bersifat menyenangkan dan jauh dari suasana yang menakutkan karena adanya hukuman, dan diyakini pendidikan akan lebih berhasil tanpa hukuman.

\section{Daftar Pustaka}

Abdulkadir Muhammad, Hukum Perdata Indonesia, (Bandung: Citra Aditya Bhakti, 1993).

Abdurrahman, Kompilasi Hukum Islam di Indonesia, (Jakarta: Akademika Pressindo, 1992).

Al-Abrasyi, Muhammad Athiyah, al-Tarbiyah alIslamiyah wa Falsafatubu, Alih bahasa Bustami Abdulghani dan Djohar Bahry, Dasar-dasar Pokok Pendidikan Islam, (Jakarta: Bulan Bintang, 1980).

al-Hamdani, Risalah Nikah, Alih bahasa Agus Salim, (Jakarta: Pustaka Amani, 1980).

Hanafi, Ahmad, Asas-asas Hukum Pidana Islam, (Jakarta; Bulan Bintang, 1990).

al-Jamal, Ibrahim Muhammad Figh Wanita, Alih bahasa Anshari Umar, (Semarang: AsySyifa, 1989).

al-Malibary, Syekh Zainuddin bi Abdul Aziz, Fathul Mu’in, Jilid 3, Ali bahasa Aliy As'ad, (Kudus: Menara, 1983).
al-Maliki, Muhammad Ali, Etika dalam Rumah Tangga Islam, Alih bahasa Halimuddin, (Surabaya: Bungkul Indah, tth).

Al-Maraghi, Ahmad Musthafa, Tafsir al-Maraghi, Juz 2 dan 4, (Semarang: Toha Putra, 1990).

al-Shan'ani, Muhammad Ismail al-Kahlani Subul alSalam, Jilid II, (Beirut: Dar al-Fikr, 1412 H). al-Sijistani, al-Imam Abi Daud Sulaiman ibn alAsy'ats, Sunan Abi Daud, Jilid 2, (Surabaya: Maktabah Dahlan Indonesia, tth).

Departemen Agama RI, Alquran dan Terjemabnya, (Jakarta: Proyek Pengadaan Kitab Suci Alquran, 1993/1994).

Departemen Komunikasi dan Informatika, Penghapusan Eksploitasi Seksual Komersial Anak, (Jakarta: Badan Informasi Publik, 2005).

Durkhem, Emile, L'Education Morale, Terjemah Lukas Ginting, Pendidikan Moral, (Jakarta: Erlangga, 2000).

Harun, Sulaiman, Sistem Pendidikan Islam, (Jakarta: Cipta Karya, 2001).

Karsayuda, Pengangkatan Anak dari Keluarga Nonmuslim di Pengadilan Agama, Bahan Perkuliahan 2006).

Mahmoud Syaltout, al-Fatawa, (Mesir: Dar alQalam, tth).

Majelis Ulama Indonesia (MUI, Himpunan Fatwa MUI, (Jakarta: Departemen Agama RI, 2003).

Masyfuk Zuhdi, Masail Fiqhiyah, (Jakarta: Haji Masagung, 1996).

Muslim, al-Imam Abi al-Husain Muslim bin alHajjaj al-Qusyairi, Shabih Muslim, (Beirut: Dar al-Fikr, $1401 \mathrm{H}$ ).

Purwanto, M. Ngalim, Ilmu Pendidikan Teoretis dan Praktis, (Bandung: Remaja Rosdakarya, 2001).

Sayyid Sabiq, Fikih Sunnah 8,9, 10, Alih bahasa M. Thalib, (Bandung: Alma'arif, 1987).

Shaleh, Qamaruddin, Asbabun Nuгul, (Bandung: Diponegoro, 1999).

Sudirman dkk, Ilmu Pendidikan, (Jakarta: Rineka Cipta, 1991).

UU Nomor 1 Tahun 1974 Tentang Perkawinan, (Surabaya: Pustaka Tintamas, 1992). 
UU Nomor 4 Tabun 1979 Tentang Kesejabteraan Anak, (Jakarta: Sinar Grafia, 2000).

UU Nomor 23 Tabun 2002 tentang Perlindungan Anak. (Jakarta: Sinar Grafia, 2003).

UU Nomor 35 tabun 2014 tentang Perubahan terbadap UU Nomor 23 Tabun 2002 tentang Perlindungan Anak. Media Online. 